\title{
Komparasi Keefektifan Saintifik dan PMRI Ditinjau dari Prestasi, Minat, dan Percaya Diri Siswa Kelas VII
}

\author{
Uki Suhendar $^{1}$, Djamilah Bondan Widjajanti ${ }^{2}$ \\ ${ }^{1}$ Jurusan Pendidikan Matematika, Universitas Muhammadiyah Ponorogo, Jalan Budi Utomo No.10, \\ Ronowijayan, Kabupaten Ponorogo, Jawa Timur 63471, Indonesia \\ ${ }^{2}$ Jurusan Pendidikan Matematika, Universitas Negeri Yogyakarta, Jalan Colombo No. 1, \\ Karangmalang, Yogyakarta 55281, Indonesia. \\ * Korespondensi Penulis. Email: uki.suhendar@yahoo.com, Telp: +6285735409793
}

Received: 15 $5^{\text {th }}$ June 2016; Revised: $24^{\text {th }}$ June 2016; Accepted: $26^{\text {th }}$ July 2016

\begin{abstract}
Abstrak
Penelitian eksperimen semu ini bertujuan untuk mendeskripsikan keefektifan Pendekatan Saintifik, mendeskripsikan keefektifan Pendekatan PMRI, dan mendeskripsikan manakah yang lebih efektif diantara Saintifik dan PMRI ditinjau dari prestasi, minat, dan percaya diri. Populasi dalam penelitian ini adalah siswa kelas VII SMPN 2 Babadan Ponorogo Jawa Timur Indonesia dan secara acak terpilih kelas VIIB dan VIIC sebagai sampel. Teknik pengumpulan data adalah tes dan non-tes, dengan instrumen meliputi soal tes prestasi, angket minat dan percaya diri. Teknik analisis data menggunakan uji t dan Hotelling's Trace. Hasil penelitian pada taraf signifikansi 0,05 menunjukkan bahwa Pendekatan Saintifik efektif ditinjau dari prestasi, minat, dan percaya diri. Pendekatan PMRI efektif ditinjau dari prestasi dan percaya diri, tetapi tidak efektif ditinjau dari minat. Saintifik dan PMRI sama-sama efektif ditinjau dari prestasi dan percaya diri, akan tetapi ditinjau dari minat Saintifik lebih unggul daripada PMRI.
\end{abstract}

Kata kunci: pendekatan saintifik, pendekatan PMRI, prestasi, minat, percaya diri

\section{The Comparison of the Effectiveness of Scientific and PMRI Approaches Based on the Achievement, Interest, and Self-Confidence of Students of Grade VII}

\begin{abstract}
This quasi-experimental research aims to describe the effectiveness of Scientific Approach, describe the effectiveness of PMRI approach, and describe which is more effective between of Scientific and PMRI Approaches in terms of the achievement, interest, and self-confidence. The population in this research were students of class VII SMPN 2 Babadan Ponorogo, East Java, Indonesia, and randomly selected VIIB and VIIC classes as a sample. The data collection techniques were a test and non-test, the instrument covers about mathematics achievement tests, questionnaires for students' interest and self-confidence. The data were analysed using the t test and the Hotelling's Trace test. The results show that at the significance level of 0.05 the Scientific Approach is effective in terms of students' achievement, interest, and self-confidence, while the PMRI Approach is effective in terms of learning achievement and self-confidence, but it is not effective in terms of interest. The Scientific and PMRI Approaches are equally effective in terms of learning achievement and selfconfidence, but in terms of interest the Scientific Approach is superior to the PMRI Approach.
\end{abstract}

Keywords: scientific approach, PMRI approach, mathematics achievement, interest, self-confidence

How to Cite: Suhendar, U., \& Widjajanti, D. (2016). Komparasi keefektifan saintifik dan PMRI ditinjau dari prestasi, minat, dan percaya diri siswa kelas VII. PYTHAGORAS: Jurnal Pendidikan Matematika, 11(1), 91-101. doi:http://dx.doi.org/10.21831/pg.v11i1.9674

Permalink/DOI: http://dx.doi.org/10.21831/pg.v11i1.9674 


\section{PENDAHULUAN}

Proses pembelajaran di sekolah secara umum bertujuan untuk mengembangkan ranah sikap, pengetahuan, dan keterampilan siswa secara utuh (holistik). Peningkatan ranah pengetahuan siswa setelah mengikuti pembelajaran di sekolah sejak dahulu telah menjadi fokus utama. Hal ini terlihat dari evaluasi hasil belajar siswa dalam Ujian Nasional sebatas pada aspek pengetahuan saja. Aspek pengetahuan merupakan definisi sempit dari prestasi belajar (O'Connor, 2009, p.90). Oleh karena itu, prestasi belajar yang tinggi sangat penting dan perlu dimiliki siswa.

Prestasi belajar matematika adalah kemampuan pengetahuan matematika siswa yang sesuai dengan tujuan pembelajaran untuk sebagian mata pelajaran matematika tertentu (O'Connor, 2009, p.90, Bloom, 1956, p.28, Lefrancois, 1985, p.255). Faktor-faktor yang mempengaruhi prestasi belajar diantaranya adalah meningkatkan kemauan untuk tekun, minat, rasa percaya diri, interaksi dengan teman atau guru, dan melakukan kegiatan-kegiatan mempelajari materi pelajaran (Arthur \& Cremin, 2010, p.20, Syah, 2010, pp. 129-136).

Gable (1986, p.9) mengaitkan minat dengan sasaran, arah, dan intensitas. Sasarannya adalah aktivitas, arahnya berupa ketertarikan atau ketidak tertarikan, dan intensitas diungkapkan dengan tinggi atau rendah. Minat adalah lebih memilih suatu aktivitas dibanding aktivitas lainnya (Sax, 1980, p.473). Bila minat belajarnya tinggi, maka siswa akan lebih memilih belajar daripada aktivitas lainnya. Upaya meningkatkan minat antara lain berinteraksi dengan teman atau guru, menghubungkan materi matematika dengan masalah kehidupan nyata, melibatkan siswa dalam kegiatan yang sesuai perkembangan mental, memberi kesempatan siswa untuk mengevaluasi hasil kerjanya, dan memberi kesempatan untuk mengintegrasikan pengetahuan yang dimiliki (Elliot, et al., 2000, p.349, Ormrod, 2003, p.402, Woolfolk, 2007, p.384).

Menurut Zimmerman, Bonner, \& Kovach (1996, pp.42-43), rasa percaya diri sangat memotivasi siswa yang belum menikmati banyak kesuksesan di sekolah. Rasa percaya diri adalah keyakinan, yaitu pemahaman dan perasaan mampu, nyaman dan puas dengan diri sendiri yang membentuk cara siswa memperoleh konsep dan terlibat dalam perilaku matematika (Parsons, Croft, \& Harrison, 2011, p.53,
Hannula, Maijala, \& Pehkonen, 2004, p.17, Molloy, 2010, p.138). upaya meningkatkan rasa percaya diri diantaranya menciptakan interaksi dengan tema atau guru, meyakini kemampuan matematika yang dimiliki, persepsi positif orang tua, menunjukkan prestasi yang dicapai, serta memunculkan suasana yang menantang dan menyenangkan di kelas (Jurdak, 2009, p.111, Elder, 1995, p.62, Schiro, 2009, p. 4).

Faktor yang mempengaruhi prestasi belajar lainnya diungkapkan oleh Syah (2010, pp.129-136), yakni pendekatan pembelajaran. Pendekatan yang berpusat pada siswa telah menjadi perhatian utama pemerintah. Hal ini dipertegas dalam Lampiran Permendikbud No 65 Tahun 2013 tentang standar proses, bahwa prinsip pembelajaran adalah dari siswa diberi tahu menuju siswa mencari tahu. Pembelajaran dengan siswa membangun pengetahuannya sendiri disebut pandangan konstruktivistik. Harapan pemerintah mengenai penerapan pendekatan berbasis konstruktivis dituangkan dalam Kurikulum 2013, yakni dengan mengenalkan pendekatan saintifik.

Pendekatan saintifik adalah suatu cara pembelajaran untuk memfasilitasi siswa agar mendapat pengetahuan atau keterampilan dengan prosedur yang didasarkan pada suatu metode ilmiah, yakni dengan bereksperimen ataupun menyelidiki suatu ide hingga diperoleh kesimpulan yang logis (Wolf, 1925, pp.15-16, Kemdikbud, 2013, p.203, Kurnik, 2008, p.421). Langkahnya dimulai dengan mengamati, menanya, mengumpulkan informasi, menalar, dan mengomunikasikan (Kemdikbud, 2014, p.185-186, Hosnan, 2014, p.37). Menghadirkan pendekatan saintifik dalam pembelajaran diharapkan akan mampu membiasakan siswa membuat hipotesis dan mengeksperimenkan segala sesuatu di sekitarnya. Akan tetapi, sebagian guru masih kebingungan melaksanakan pendekatan ini di kelas (Mulyasa, 2013, p.36).

Khusus dalam matematika telah dikenal Pendekatan Pendidikan Matematika Realistik Indonesia (PMRI) yang juga berorientasi pada konstruktivistik. PMRI adalah suatu pendekatan pembelajaran yang membimbing siswa dengan menggunakan masalah-masalah realistik di awal pembelajaran untuk menuju matematika yang abstrak, dengan proses matematisasi horisontal dan vertikal (Gravemeijer, 1994, pp.21, 94, 114115, Uzel \& Uyangor, 2006, p.1952, De Lange, 1996, pp. 56-57, van den Heuvel-Panhuizen, 2000, p.4, Hadi, 2005, p.21). Langkahnya adalah mengamati masalah yang realistik, melakukan 
matematisasi horizontal, melakukan matematisasi vertikal, mengomunikasikan secara interaktif, melakukan refleksi (Hadi, 2005, p.37, Uzel \& Uyangor, 2006, p.1954, Oktorizal, Elniati, \& Suherman, 2012, p.62, Fauzan, 2002, p.35, Sugiman, 2011, p.8, Ozdemir \& Uzel, 2011, p.332).

Salah satu karakteristik pendekatan saintifik menurut Kemdikbud (2013, p.203) adalah pembelajaran diarahkan untuk mampu merumuskan masalah (menanya), bukan hanya menyelesaikan masalah (menjawab). Artinya siswa memperoleh konsep dengan merumuskan masalah terlebih dahulu kemudian mencari bukti untuk memperoleh jawaban. Di sisi lain, Gravemeijer (1994, pp.114-115) mengungkapkan bahwa salahsatu karakteristik pendekatan PMRI adalah penggunaan model. Diartikan bahwa siswa memperoleh konsep diawali dengan memodelkan secara informal kemudian menuju matematika formal. Karakteristik inilah salah satu perbedaan diantara keduanya, namun demikian keduanya sama-sama menekankan konstruksi pengetahuan oleh siswa sendiri.

Bila melihat hasil Ujian Nasional (UN) yang diolah oleh Badan Standar Nasional Pendidikan (BSNP), maka perubahan prinsip pembelajaran menjadi konstruktivis mungkin memang dibutuhkan dalam pendidikan di Indonesia, khususnya di SMPN 2 Babadan Ponorogo, Jawa Timur Indonesia. Data daya serap UN pada Kompetensi Dasar 3.3 yakni menyelesaikan persamaan linier dan pertidaksamaan linier satu variabel, menunjukkan masalah yang cukup serius dalam pembelajaran matematika di SMPN 2 Babadan Ponorogo Jawa Timur Indonesia. Data daya serap pada kompetensi ini naik turun tiap tahun, bahkan di tahun 2013 persentase daya serap soal terkait menyelesaikan persamaan linear dan pertidaksamaan linear satu variabel hanya sebesar $65.50 \%$. Artinya, sebagian siswa masih cukup kesulitan menyelesaikan soal terkait persamaan atau pertidaksamaan linear satu variabel.

Berdasarkan observasi peneliti, diduga hal tersebut akibat minat yang belum maksimal. Ditunjukkan oleh sebagian siswa yang lebih menikmati kegiatan lain saat pembelajaran matematika berlangsung, seperti ijin mengikuti rapat OSIS, menggambar tokoh kartun di buku catatannya, dan mengobrol dengan teman. Salah satu penyebabnya mungkin karena seringnya pembelajaran berorientasi pada buku dan kurang terkait dengan kehidupan siswa. Oleh karenanya siswa merasa matematika kurang bermanfaat dalam kehidupan.

Sebagian besar siswa juga cenderung takut salah ketika disuruh mengerjakan soal yang sedikit berbeda dengan contoh yang diberikan. Hal ini mungkin disebabkan oleh kurang aktifnya siswa membangun pengetahuan bagi diri sendiri. Selain itu, jika disuruh menunjukkan hasil mengerjakan latihan di depan kelas maka sebagian siswa menolak dengan alasan tidak bisa, padahal mereka telah mencoba di buku masing-masing. Jadi dapat dikatakan bahwa rasa percaya diri siswa juga masih perlu ditingkatkan lagi.

Hasil observasi tersebut juga didukung hasil penelitian awal yang dilakukan peneliti di SMPN 2 Babadan Ponorogo, Jawa Timur, Indonesia. Penelitian dilakukan dengan memberikan angket modifikasi buatan Rakhmawati (2012, p.195) dan Hapsari (2012, p.215) mengenai minat dan percaya diri siswa SMP. Sebanyak $42.10 \%$ siswa mempunyai minat dengan kategori lebih dari cukup. Bahkan, untuk pernyataan siswa merasa terbebani dengan tugas matematika yang diberikan guru dan bosan dalam mempelajari matematika berturut-turut hanya 4 dan 5 dari 19 siswa yang menjawab jarang. Demikian halnya mengenai rasa percaya diri, hasilnya $5.26 \%$ siswa saja yang mempunyai rasa percaya diri pada kategori tinggi.

Secara teoritis, pendekatan dengan prinsip pembelajaran konstruktivis dapat meningkatkan aspek pengetahuan maupun sikap siswa. Hal ini juga telah didukung beberapa hasil penelitian. Salahsatunya, hasil penelitian yang dikemukakan oleh Uzel \& Uyangor (2006, p.1952) menyatakan bahwa sikap siswa terhadap matematika menjadi positif setelah diberi pembelajaran dengan PMR yang berdasar pada konstruktivistik. Selain itu, Zaini \& Marsigit (2014, p.152) juga menyataka bahwa pembelajaran PMR lebih baik dari pembelajaran konvensional ditinjau dari kemampuan penalaran dan komunikasi matematika siswa. Dengan demikian, pendekatan konstruktivis seperti saintifik dan PMRI kemungkinan besar mampu menyelesaikan permasalahan tentang prestasi belajar, minat, dan rasa percaya diri siswa kelas VII SMPN 2 Babadan Ponorogo Jawa Timur Indonesia.

Akan tetapi, di Indonesia pendekatan saintifik masih baru dikenal dibandingkan pendekatan PMRI, maka kajian empiris yang membandingkan keduanya pun masih sedikit di Ponorogo. Selain itu juga banyak kesamaan diantara dua pendekatan tersebut. Dengan demi- 
kian, tentunya kajian mendalam mengenai keefektifan implementasi pendekatan saintifik dan PMRI sangat diperlukan. Oleh karena itu, peneliti ingin melakukan penelitian untuk membandingkan keefektifan saintifik dan PMRI ditinjau dari prestasi belajar, minat dan rasa percaya diri siswa kelas VII SMP.

Berdasarkan uraian tersebut, penelitian ini dilaksanakan untuk mendeskripsikan keefektifan pendekatan saintifik, mendeskripsikan keefektifan pendekatan PMRI, serta untuk mendeskripsikan mana yang lebih efektif diantara pendekatan saintifik dan pendekatan PMRI ditinjau dari prestasi, minat, dan percaya diri siswa kelas VII SMP N 2 Babadan Ponorogo.

\section{METODE}

Jenis penelitian ini adalah penelitian eksperimen semu. Penelitian dilaksanakan di SMPN 2 Babadan Ponorogo Jawa Timur Indonesia, pada tanggal 16 Maret-11April 2015. Populasi dalam penelitian ini adalah semua siswa kelas VII SMPN 2 Babadan Ponorogo Jawa Timur Indonesia yang terdiri atas empat kelas. Pengambilan sampel dilakukan dengan mengambil secara acak sebanyak dua kelas dari empat kelas yang ada, dan terpilih kelas VIIB dan VIIC. Kemudian dari dua kelas tersebut kembali dilakukan pengacakan untuk menentukan kelas yang diberi perlakuan, terpilih kelas VIIB diberi perlakuan pendekatan saintifik dan kelas VIIC diberi perlakuan pendekatan PMRI.

Langkah pertama yang dilakukan dalam penelitian ini adalah mengambil secara acak dua kelas sebagai kelompok eksperimen. Kemudian memberikan instrumen tes dan non-tes pada dua kelas terpilih sebelum perlakuan. Lalu memberi perlakuan sebanyak 8 pertemuan dengan menerapkan pendekatan saintifik dan pendekatan PMRI pada dua kelas terpilih dengan terlebih dahulu dilakukan pengacakan. Selanjutnya memberikan instrumen tes dan non-tes pada dua kelas terpilih setelah perlakuan.

Pengumpulan data dalam penelitian ini diperoleh dengan teknik tes dan non-tes untuk kedua kelas eksperimen. Teknik tes dan non-tes dilaksanakan sebelum dan sesudah pemberian perlakuan. Tes digunakan untuk mengukur prestasi belajar matematika siswa menggunakan instrumen soal tes prestasi hingga diperoleh hasil tes prestasi. Teknik non-tes berupa angket minat dan rasa percaya diri siswa terhadap matematika untuk memperoleh skor angket minat dan percaya diri.
Analisis data yang digunakan meliputi analisis deskriptif dan inferensial. Analisis deskriptif digunakan untuk menyajikan hasil penelitian mengenai variabel prestasi, minat, dan percaya diri, baik sebelum dan sesudah perlakuan pada kelompok eksperimen pen-dekatan saintifik maupun pendekatan PMRI. Teknik statistik yang digunakan untuk mendeskripsikan hasil penelitian meliputi rata-rata, simpangan baku, skor maksimum, dan skor minimum.

Analisis secara inferensial dalam penelitian ini meliputi hasil skor prestasi belajar, minat, dan percaya diri. Sesuai dengan rumusan masalah, ada 3 hipotesis penelitian yang akan diuji. Pengujian hipotesis dilakukan menggunakan uji-t dan uji Hotelling's Trace. Keefektifan pendekatan pembelajaran dalam penelitian ini ditentukan berdasarkan indeks keefektifan. Berdasarkan kriteria ketuntasan minimal (KKM) belajar matematika di SMP N 2 Babadan Ponorogo, Jawa Timur, Indonesia yakni 75 untuk skala 1-100. Pendekatan pembelajaran dikatakan efektif ditinjau dari prestasi belajar jika nilai rata-rata siswa lebih dari 74 . Keefektifan ditinjau dari aspek sikap (minat dan percaya diri) disesuaikan dengan kriteria minat dan percaya diri yang telah ditetapkan yaitu skor 114. Hal ini dikarenakan skor 114 termasuk skor kategori tinggi dalam kriteria minat maupun percaya diri.

\section{HASIL DAN PEMBAHASAN}

Hasil tes prestasi belajar pada kelas saintifik dan PMRI dideskripsikan berdasarkan nilai tes sebelum dan sesudah perlakuan yang disajikan dalam Tabel 1.

Tabel 1. Hasil Tes Prestasi Belajar

\begin{tabular}{lcccc}
\hline \multirow{2}{*}{ Nilai } & \multicolumn{2}{c}{ Kelas Saintifik } & \multicolumn{2}{c}{ Kelas PMRI } \\
\cline { 2 - 5 } & $\begin{array}{c}\text { Tes } \\
\text { Awal }\end{array}$ & $\begin{array}{c}\text { Tes } \\
\text { Akhir }\end{array}$ & $\begin{array}{c}\text { Tes } \\
\text { Awal }\end{array}$ & $\begin{array}{c}\text { Tes } \\
\text { Akhir }\end{array}$ \\
\hline Rata-rata & 25,71 & 76,67 & 24,52 & 77,62 \\
Standar deviasi & 11,54 & 7,47 & 11,61 & 9,44 \\
Nilai tertinggi & 60 & 95 & 60 & 95 \\
Nilai terendah & 10 & 60 & 10 & 50 \\
\hline
\end{tabular}

Berdasarkan Tabel 1 dapat diketahui bahwa sebelum perlakuan rata-rata prestasi belajar matematika siswa pada kelas dengan pendekatan saintifik lebih tinggi dibandingkan kelas dengan pendekatan PMRI sebesar 1,19. Untuk rata-rata setelah perlakuan, prestasi belajar matematika siswa pada kelas dengan pendekatan PMRI lebih tinggi 0,95 dibandingkan kelas dengan pendekatan saintifik. Rata-rata tes prestasi belajar matematika siswa pada kelas dengan pendekatan saintifik mengalami peningkatan sebesar 50,95 
setelah diberikan perlakuan, sedangkan pada kelas dengan pendekatan PMRI mengalami peningkatan rata-rata sebesar 53,10.

Hasil angket minat siswa terhadap matematika pada kelas dengan pendekatan saintifik dan kelas dengan pendekatan PMRI disajikan dalam Tabel 2.

Tabel 2. Hasil Angket Minat

\begin{tabular}{lcccc}
\hline \multirow{2}{*}{ Nilai } & \multicolumn{2}{c}{ Kelas Saintifik } & \multicolumn{2}{c}{ Kelas PMRI } \\
\cline { 2 - 5 } & Awal & Akhir & Awal & Akhir \\
\hline Rata-rata & 84 & 118 & 85 & 117 \\
Standar deviasi & 9,46 & 8,09 & 9,30 & 8,66 \\
Skor tertinggi & 100 & 133 & 103 & 131 \\
Skor terendah & 71 & 102 & 69 & 101 \\
\hline
\end{tabular}

Berdasarkan Tabel 2 dapat diketahui bahwa sebelum dan sesudah perlakuan, skor ratarata dan standar deviasi minat siswa terhadap matematika pada kelas dengan pendekatan saintifik hampir sama dengan kelas dengan pendekatan PMRI. Skor rata-rata minat siswa kelas dengan pendekatan saintifik meningkat sebesar 34 poin sedangkan kelas dengan pendekatan PMRI meningkat sebesar 32 poin.

Hasil angket percaya diri siswa terhadap matematika pada kelas dengan pendekatan saintifik dan PMRI disajikan dalam Tabel 3.

Tabel 4. Hasil Angket Percaya Diri

\begin{tabular}{lcccc}
\hline \multirow{2}{*}{ Nilai } & \multicolumn{2}{c}{ Kelas Saintifik } & \multicolumn{2}{c}{ Kelas PMRI } \\
\cline { 2 - 5 } & Awal & Akhir & Awal & Akhir \\
\hline Rata-rata & 71 & 117 & 70 & 118 \\
Standar deviasi & 5,71 & 5,78 & 3,94 & 7,35 \\
Skor tertinggi & 85 & 128 & 79 & 130 \\
Skor terendah & 61 & 101 & 61 & 105 \\
\hline
\end{tabular}

Berdasarkan Tabel 3 dapat diketahui bahwa sebelum dan sesudah perlakuan, rata-rata skor percaya diri siswa terhadap matematika pada kelas dengan pendekatan saintifik hampir sama dengan kelas dengan pendekatan PMRI. Demikian halnya standar deviasi skor percaya diri pada kelas dengan pendekatan saintifik, akan tetapi standar deviasi kelas dengan pendekatan PMRI meningkat sebesar 3,404. Rata-rata skor percaya diri siswa kelas dengan pendekatan saintifik meningkat sebesar 46 poin sedangkan kelas dengan pendekatan PMRI meningkat sebesar 48 poin.

Digunakan uji-t untuk mengukur keefektifan pendekatan saintifik dan PMRI. Namun, sebelum dapat diuji dengan uji-t, maka harus memenuhi beberapa asumsi. Berikut hasil uji asumsi normalitas masing-masing variabel terikat disajikan pada Tabel 4.
Tabel 4. Hasil Uji Normalitas Univariat

\begin{tabular}{clcccc}
\hline \multirow{2}{*}{ Variabel } & \multirow{2}{*}{ Kelas } & \multicolumn{2}{c}{ Sebelum } & \multicolumn{2}{c}{ Sesudah } \\
\cline { 3 - 6 } & & Sig. & Ket. & Sig. & Ket. \\
\hline Prestasi & Saintifik & 0,135 & Normal & 0,059 & Normal \\
Belajar & PMRI & $0,090 *$ & Normal & 0,111 & Normal \\
Minat & Saintifik & $0,200^{*}$ & Normal & $0,200^{*}$ & Normal \\
& PMRI & $0,200^{*}$ & Normal & $0,200^{*}$ & Normal \\
Rasa & Saintifik & $0,200^{*}$ & Normal & 0,062 & Normal \\
Percaya Diri & PMRI & $0,200^{*}$ & Normal & $0,200^{*}$ & Normal \\
\hline
\end{tabular}

Berdasarkan Tabel 4 terlihat masing-masing variabel terikat pada kedua kelas memiliki nilai signifikansi lebih besar dari 0,05 sehingga disimpulkan bahwa asumsi normalitas untuk masing-masing variabel terpenuhi.

Hasil output SPSS yang menguji homogenitas antara dua kelas pada tiap variabel terikat diberikan pada Tabel 5 dan Tabel 6.

Tabel 5. Hasil Uji Homogenitas Sebelum Perlakuan

\begin{tabular}{lccccc}
\hline Variabel & $\begin{array}{c}\text { Levene } \\
\text { Statistic }\end{array}$ & df1 & df2 & Sig. & Ket. \\
\hline Prestasi & 0.017 & 1 & 40 & 0,898 & Homogen \\
Minat & 0,240 & 1 & 40 & 0,627 & Homogen \\
Percaya & 2,891 & 1 & 40 & 0,097 & Homogen \\
Diri & & & & & \\
\hline
\end{tabular}

Tabel 6. Hasil Uji Homogenitas Sesudah Perlakuan

\begin{tabular}{cccccc}
\hline Variabel & Levene Statistic & df1 & df2 & Sig. & Ket. \\
\hline Prestasi & 1,453 & 1 & 40 & 0,235 & Homogen \\
Minat & 0,367 & 1 & 40 & 0,548 & Homogen \\
Percaya Diri & 2,789 & 1 & 40 & 0,103 & Homogen \\
\hline
\end{tabular}

Berdasarkan Tabel 5 dan Tabel 6, dapat disimpulkan bahwa homogenitas tiap variabel terikat sebelum dan sesudah perlakuan terpenuhi. Hasil uji-t dua sampel pada hasil sebelum perlakuan dengan bantuan program SPSS, hasilnya pada Tabel 7.

Tabel 7. Hasil Uji-t Sebelum Perlakuan

\begin{tabular}{lcccc}
\hline & $\begin{array}{c}\text { Variabel } \\
(\mathbf{x})\end{array}$ & Sign. & Df & $\mathbf{t}_{\text {hitung }}$ \\
\hline Kelas Saintifik & Prestasi & 0,741 & 40 & 0,333 \\
dibandingkan & Minat & 0,819 & 40 & $-0,230$ \\
PMRI & Percaya & 0,291 & 40 & 1,070 \\
\hline \multicolumn{2}{r}{} & Diri & & 2,021 \\
\hline
\end{tabular}

Hasil uji-t pada Tabel 7 menunjukkan bahwa $t_{\text {hitung }}$ masing-masing variabel terikat kurang dari $t_{\text {tabel}}$, juga nilai signifikansi pada masing-masing variabel lebih dari 0,05 , sehingga pada taraf signifikansi $5 \% \quad H_{0}$ diterima. Jadi, sebelum diberikan perlakuan tidak terdapat perbedaan rata-rata antar variabel terikat, yakni 
prestasi, minat, dan percaya diri siswa, antara kelas dengan pendekatan saintifik dan kelas dengan pendekatan PMRI.

Berdasarkan perhitungan diperoleh nilai $t$ hitung sebesar 1,776. Nilai t hitung yang diperoleh lebih besar dari $\mathrm{t}_{\text {tabel }}=t_{0,05 ; 20}=1,725$ sehingga Ho ditolak. Dengan demikian disimpulkan bahwa pada taraf signifikansi 5\%, saintifik efektif ditinjau dari prestasi.

Hasil ini sesuai dengan kerangka berpikir peneliti, yakni kelima langkah pendekatan saintifik mampu meningkatkan prestasi belajar. Juga menurut Cobern (1993, p.1) yang mengungkapkan pendekatan pembelajaran yang berbasis konstruktivis mampu meningkatkan atau mengembangkan pengetahuan yang telah dimiliki sebelumnya, salah satunya pendekatan saintifik.

Berdasarkan skor prestasi belajar diperoleh peningkatan rata-rata prestasi sebelum dan sesudah perlakuan di kelas dengan pendekatan saintifik sekitar $200 \%$. Setelah perlakuan banyak siswa yang mendapat nilai dibawah KKM hanya 5 dari 21 siswa dengan rata-rata 67. Bila ditinjau dari butir yang banyak dijawab salah oleh siswa setelah pembelajaran, maka diperoleh butir 16, 19, dan 20. Ketiganya tentang memodelkan serta menyelesaikan masalah terkait PtLSV. Kesalahan siswa karena masih belum bisa memahami makna serta mengubah ke model matematika. Seperti pada butir 16, 5 dari 7 siswa yang menjawab salah memilih pilihan jawaban C. Pengecohnya adalah frase "masih tersisa 120" yang harusnya diubah menjadi model matematisnya "+120" tetapi terkecoh dengan "-120".

Walaupun demikian, bila dibandingkan dengan tes awal, maka untuk ketiga butir tersebut mengalami peningkatan jumlah siswa menjawab benar yang cukup signifikan setelah perlakuan. Misalnya butir 20, saat tes awal banyak siswa yang menjawab salah sebanyak 20 orang, akan tetapi setelah diberi perlakuan pendekatan saintifik banyak siswa yang menjawab salah hanya 8 orang. Hal ini sesuai dengan pendapat Adams \& Hamm (2010, p.87), yakni dengan kegiatan saintifik maka akan melahirkan generasi yang inovatif. Hal ini berarti bahwa dengan pendekatan saintifik telah membuat sekitar 12 siswa menjadi lebih inovatif sehingga mampu memaknai serta memodelkan permasalahan dengan benar.

Penerapan pendekatan saintifik yang terbukti mampu meningkatkan prestasi belajar siswa dalam pembelajaran matematika sebanding dengan persiapan guru sebelum penerapan- nya. Kelima langkah dalam pendekatan saintifik membutuhkan perancangan matang dan kreativitas tinggi. Seorang guru yang akan menerapkannya butuh lebih banyak waktu perencanaan dibandingkan pelaksanaan. Selain itu bimbingan guru juga berperan, saat kegiatan siswa keluar perencanaan maka sang guru harus segera membimbing dengan tepat.

Berdasarkan perhitungan diperoleh nilai $\mathrm{t}$ hitung sebesar 1,996. Nilai t hitung yang diperoleh tersebut lebih besar dari $t_{\text {tabel }}=1,725$ sehingga Ho ditolak. Dengan demikian disimpulkan bahwa pada taraf signifikansi 5\%, saintifik efektif ditinjau dari minat. Berdasarkan hasil pengujian hipotesis disimpulkan bahwa pendekatan saintifik efektif ditinjau dari minat siswa SMP N 2 Babadan Ponorogo Jawa Timur Indonesia. Bahkan jika diamati dari rata-rata tiap indikator peningkatannya sangat signifikan, yakni sekitar 1,000. Peningkatan tertinggi pada indikator Ketertarikan, maka dapat dikatakan bahwa saintifik mampu membuat siswa tertarik pada matematika dari berbagai aspek pembelajaran. Hal ini dapat dipercaya karena pada langkah-langkah pembelajaran saintifik sangat mendorong siswa untuk ikut berpartisipasi aktif, baik secara individu maupun kelompok.

Berdasarkan hasil penelitian diperoleh peningkatan skor tertinggi setelah perlakuan adalah sebesar 53, sedangkan peningkatan terendah sebesar 13. Hal ini sesuai dengan hasil uji hipotesis, karena setelah perlakuan, minat siswa meningkat semua walaupun dengan peningkatan yang beragam. Ditinjau dari peningkatan skor tiap butir, butir 8 meningkat sebanyak 40 skor. Ini adalah salah satu butir yang terkait pendekatan pembelajaran, yakni mengenai keterlibatan mengikuti presentasi matematika. Sesuai pendapat Elliot, et al. (2010, p.349) dan kesimpulan peneliti bahwa salah satu upaya meningkatkan minat adalah dengan berinteraksi. Oleh karenanya peneliti meyakini inilah salah satu penyebab efektifnya pendekatan saintifik ditinjau dari minat.

Berdasarkan hasil perhitungan yang selanjutnya diperoleh nilai t hitung sebesar 2,568. Nilai thitung yang diperoleh tersebut lebih besar dari $\mathrm{t}_{\text {tabel }}=1,725$ sehingga Ho ditolak. Jadi pada taraf signifikansi 5\%, saintifik efektif ditinjau dari percaya diri. Hasil penelitian menunjukkan bahwa saintifik efektif ditinjau dari rasa percaya diri siswa SMP N 2 Babadan Ponorogo, Jawa Timur, Indonesia. Pembelajaran dengan pendekatan saintifik melalui langkah menanya dan mengomunikasikan diyakini peneliti dapat 
meningkatkan rasa percaya diri siswa. Pada langkah ini siswa diajari cara mengungkapkan ide yang dimiliki kepada orang lain, tentu hal ini mampu melatih keberanian mereka. Pada langkah menalar siswa bekerja secara kelompok setelah bekerja individu. Saat berada dalam kelompok, siswa dilatih untuk bersosialisasi dengan orang lain. Siswa diharapkan aktif menyampaikan pendapat maupun mengajukan pertanyaan dalam berdiskusi dengan temannya. Pada akhir pembelajaran, perwakilan siswa dari beberapa kelompok diminta mempresentasikan pekerjaannya. Pada tahap ini siswa dilatih agar lebih percaya diri untuk tampil di depan kelas maupun untuk menyampaikan pendapat. Hal ini tentunya mendukung peningkatan rasa percaya diri siswa. Memperkuat bahasan ini, Elder (1995, p.62) berpendapat bahwa penerimaan teman sejawat juga mampu meningkatkan rasa percaya diri.

Berdasarkan hasil skor percaya diri siswa diperoleh peningkatan skor tertinggi setelah perlakuan adalah sebesar 85, sedangkan peningkatan terendah sebesar 61 . Hal ini sesuai dengan hasil uji hipotesis, karena setelah pembelajaran percaya diri siswa meningkat semua walaupun dengan peningkatan yang beragam. Ditinjau dari peningkatan skor tiap butir, butir 16 meningkat sebanyak 52 skor merupakan butir dengan peningkatan tertinggi. Ini adalah salah satu butir yang terkait dengan pendekatan pembelajaran, yakni mengenai keberanian diri untuk mengungkapkan pendapat dalam kelompok diskusi. Sebelumnya peneliti menyimpulkan salah satu upaya meningkatkan percaya diri melalui adanya interaksi dengan teman. Oleh karena adanya diskusi membuat saintifik efektif ditinjau dari percaya diri.

Selanjutnya, perhitungan diperoleh nilai t hitung sebesar 1,757 . Nilai $t$ hitung ini lebih besar dari $\mathrm{t}_{\text {tabel }}=t_{0,05 ; 20}=1,725$ sehingga Ho ditolak. Disimpulkan bahwa pada taraf signifikansi 5\%, pendekatan PMRI efektif ditinjau dari prestasi. Kesimpulan yang diperoleh berdasarkan hasil pengujian hipotesis adalah pendekatan PMRI efektif ditinjau dari prestasi siswa SMP N 2 Babadan Ponorogo. Hal ini juga sesuai dengan kerangka berpikir peneliti, yakni kelima langkah pada pendekatan PMRI mampu meningkatkan prestasi belajar siswa. Sesuai juga dengan hasil penelitian oleh Widiyanti (2012, p.125) yang menyimpulkan bahwa pendekatan PMRI berpengaruh lebih besar terhadap kemampuan kognitif dibanding pendekatan konvensional.
Berdasarkan deskripsi hasil penelitian sebelum dan sesudah perlakuan diperoleh peningkatan rata-rata prestasi belajar di kelas PMRI sekitar $200 \%$. Siswa yang mendapat nilai dibawah KKM hanya 5 diantara 21 siswa dengan rata-rata 64. Melihat dari butir yang banyak dijawab salah oleh siswa setelah pembelajaran, juga diperoleh no 16,19 , dan 20 . Ketiganya tentang memodelkan serta menyelesaikan masalah terkait PtLSV. Kesalahan siswa diantaranya karena masih salah dalam melakukan operasi aljabar. Seperti pada butir 19, 7 dari 10 siswa yang menjawab salah memilih pilihan jawaban B. Salahnya kemungkinan karena operasi aljabar yang harusnya ditambah 3 tetapi dikurangi 3, dan belum disubstitusikan ke soal.

Penerapan PMRI yang teruji mampu meningkatkan prestasi siswa berbanding lurus dengan apa yang harus dipersiapkan guru sebelum penerapannya. PMRI membutuhkan ide-ide kreatif dalam penerapannya. Seorang guru yang akan menerapkannya butuh lebih banyak waktu untuk persiapan. Hal ini sesuai pendapat Sembiring (2010, p.12), bahwa salah satu karakteristik pendekatan PMRI adalah peran guru yang harus lebih aktif dalam merancang bahan ajar dan kegiatan kelas.

Analisis yang dilakukan selanjutnya adalah analisis tentang eefektifan pendekatan PMRI ditinjau dari minat. Berdasarkan perhitungan diperoleh nilai $t$ hitung sebesar 1,336. Nilai $t$ hitung yang diperoleh tersebut lebih kecil dari $\mathrm{t}_{\text {tabel }}=1,725$ sehingga Ho diterima. Disimpulkan bahwa pada taraf signifikansi $5 \%$, pendekatan PMRI tidak efektif ditinjau dari minat. Berdasarkan hasil pengujian hipotesis diperoleh kesimpulan bahwa PMRI tidak efektif ditinjau dari minat siswa SMPN 2 Babadan Ponorogo, Jawa Timur, Indonesia. Peningkatan skor ratarata per indikator yang rendah adalah pada indikator Pilihan dan Ketertarikan, sehingga dapat disimpulkan bahwa siswa kelas PMRI belum terlalu berminat terhadap matematika ditinjau dari pilihan dan ketertarikan. Hal ini disimpulkan peneliti yang menyebabkan mengapa PMRI tidak efektif ditinjau dari minat dalam penelitian ini.

Berdasarkan hasil penelitian diperoleh peningkatan skor tertinggi setelah perlakuan adalah sebesar 47, sedangkan peningkatan terendah sebesar 15. Walaupun setelah pembelajaran minat siswa meningkat semua namun ternyata PMRI tidak efektif untuk mening-katkan minat. Ditinjau dari peningkatan skor tiap butir, butir 23 meningkat sebanyak 4 skor merupakan butir 
dengan peningkatan terendah. Ini adalah salah satu butir yang terkait dengan pendekatan pembelajaran, yakni keterlibatan siswa dalam menyelesaikan soal secara individu sebelum dibahas bersama. Sesuai pendapat Ormrod (2003, p.402) bahwa salah satu upaya meningkatkan minat adalah dengan melibatkan siswa secara aktif. Walaupun dalam proses pembelajaran telah diberi kesempatan untuk aktif, namun dalam prosesnya tidak semua siswa tertarik. Misalnya saat diberi kesempatan untuk memodelkan permasalahan, ada siswa tidak menyelesaikan sesuai perintah, kadang mengerjakannya dengan melihat milik teman. Oleh karenanya peneliti meyakini ini salah satu penyebab tidak efektifnya PMRI ditinjau dari minat.

Analisis tentang keefektifan pendekatan PMRI ditinjau dari rasa percaya diri diperoleh nilai t hitung sebesar 2,554. Nilai t hitung yang diperoleh tersebut lebih besar dari $t_{\text {tabel }}=1,725$ sehingga Ho ditolak. Dengan demikian dapat disimpulkan bahwa pada taraf signifikansi 5\%, pendekatan PMRI efektif ditinjau dari rasa percaya diri. Hasil penelitian menunjukkan bahwa PMRI efektif ditinjau dari percaya diri siswa SMP N 2 Babadan Ponorogo, Jawa Timur, Indonesia. Pembelajaran dengan PMRI melalui langkah melakukan matematisasi horizontal, mengomunikasikan secara interaktif, dan refleksi dipercaya dapat meningkatkan percaya diri siswa. Siswa diajari bagaimana cara mengungkapkan ide yang dimiliki secara tertulis, diadu ke siswa lain, tentunya mampu melatih keberanian mereka.

Berdasarkan hasil penelitian diperoleh peningkatan skor tertinggi setelah perlakuan sebesar 60 , peningkatan terendah sebesar 36 . Hal ini sesuai dengan hasil uji hipotesis, karena setelah pembelajaran percaya diri meningkat semua walaupun dengan peningkatan yang beragam. Ditinjau dari peningkatan skor tiap butir, butir 17 meningkat sebanyak 58 skor merupakan butir dengan peningkatan tertinggi. Ini adalah salah satu butir terkait pendekatan pembelajaran, yakni tentang keberanian diri untuk presentasi tanpa ditunjuk guru. Sebelumnya, Jurdak (2009, p.111) dan Schiro (2009, p.4) berpendapat bahwa salah satu upaya meningkatkan percaya diri melalui terciptanya interaksi dengan teman. Oleh karena adanya presentasi dengan inisiatif sendiri, menurut peneliti menjadi penyebab efektifnya PMRI ditinjau dari percaya diri dalam penelitian ini.

Perbandingan keefektifan antar kedua pendekatan tersebut dilakukan dengan uji
Hotelling's Trace, oleh karenanya harus memenuhi uji asumsi multivariat terlebih dahulu. Akan tetapi berdasarkan hasil keefektifan PMRI, maka untuk variabel minat sudah tidak diikutkan lagi dalam perhitungan.

Pengujian asumsi normalitas multivariat dilihat dari pemenuhan asumsi kenormalan multivariat menggunakan kriteria yaitu jika sekitar $50 \%$ nilai $d_{i}^{2}<\chi_{0,5(p)}^{2}$ maka dapat dikatakan bahwa hasil tersebut berasal dari populasi yang berdistribusi normal. Tabel 8 berikut adalah ringkasan uji asumsi normalitas multivariat.

Tabel 8. Hasil Uji Normalitas Multivariat

\begin{tabular}{cccc}
\hline Kelas & Jenis & $\begin{array}{c}\text { Persentase } \\
\text { banyak siswa } \\
\text { dengan nilai } \\
\left.\boldsymbol{d}_{\boldsymbol{i}}^{\mathbf{2}}<\boldsymbol{\chi}_{\mathbf{0 . 5}}^{\mathbf{2}} \boldsymbol{p}\right)\end{array}$ & Ket. \\
\hline \multirow{2}{*}{ Saintifik } & Awal & 61,90 & Normal \\
& Akhir & 47,62 & Normal \\
PMRI & Awal & 61,90 & Normal \\
& Akhir & 61,90 & Normal \\
\hline
\end{tabular}

Berdasarkan hasil uji pada Tabel 8 dapat disimpulkan bahwa kelas saintifik dan PMRI memenuhi asumsi normal multivariat. Hasil analisis uji homogenitas multivariat disajikan pada Tabel 9.

Tabel 9. Hasil Uji Homogenitas Multivariat

\begin{tabular}{cccc}
\hline Jenis & Box's M & Sig. & Ket. \\
\hline Awal & 3,157 & 0,394 & Homogen \\
Akhir & 2,067 & 0,582 & Homogen \\
\hline
\end{tabular}

Berdasarkan Tabel 9 dapat disimpulkan bahwa pada taraf signifikansi 0,05, asumsi homogenitas sebelum dan sesudah perlakuan terpenuhi. Hasil uji multivariat pada hasil sebelum perlakuan menggunakan uji Hotelling's Trace dengan bantuan program SPSS adalah sebagai berikut.

Tabel 10. Hasil Uji Multivariat Sebelum Perlakuan

\begin{tabular}{cccc}
\hline Effect & Value & F & Sig. \\
\hline Hotelling's Trace & 0,011 & $0,207^{\mathrm{b}}$ & 0,814 \\
\hline
\end{tabular}

Tabel 10 menunjukkan bahwa nilai signifikansi $0,814>0,05$ sehingga pada taraf signifikansi $5 \% H_{0}$ diterima. Jadi, disimpulkan bahwa pada sebelum perlakuan tidak terdapat perbedaan rata-rata prestasi dan percaya diri siswa antara kelas saintifik dan PMRI.

Karena asumsi dan kesamaan kondisi awal terbukti dipenuhi, maka untuk membandingkan keefektifan dua pendekatan cukup menggunakan uji Hotelling's Trace terhadap 
hasil setelah perlakuan.

Tabel 11. Hasil Uji Multivariat Setelah Perlakuan

\begin{tabular}{cccc}
\hline Effect & Value & F & Sig \\
\hline Hotelling's Trace & 0,011 & $0.207^{\mathrm{b}}$ & 0,814 \\
\hline
\end{tabular}

Hasil pada Tabel 11 menunjukkan bahwa nilai sig. $0,814>0,05$. Dengan demikian disimpulkan bahwa pada taraf signifikansi 0,05 tidak terdapat perbedaan rata-rata prestasi dan percaya diri pada kelas saintifik dan PMRI.

Hasil penelitian menunjukkan saintifik sama-sama efektif dibandingkan PMRI ditinjau dari prestasi. Hal ini sesuai dengan hipotesis penelitian. Cobern (1993, p.1) mengungkapkan bahwa pendekatan yang berbasis konstruktivis mampu meningkatkan atau mengembangkan pengetahuan yang telah dimiliki sebelumnya. Dikarenakan saintifik dan PMRI keduanya sama-sama berbasis konstruktivis inilah maka peneliti percaya keduanya sama-sama efektif ditinjau dari prestasi.

Hasil penelitian menunjukkan rata-rata prestasi belajar siswa mengalami peningkatan signifikan di kedua kelas. Rata-rata prestasi yang dicapai setelah perlakuan di kedua kelas lebih tinggi dari KKM. Selain itu, tingkat ketuntasan kelas PMRI dengan saintifik sama besar. Berdasarkan hasil penelitian, materi yang belum dikuasai pada kedua kelas hampir sama, yakni tentang memodelkan dan menyelesaikan model permasalahan PLSV dan PtLSV. Namun setelah perlakuan, pada kelas saintifik materi menyelesaikan PLSV dalam bentuk pecahan dan memodelkan masalah PLSV juga belum dikuasai, sedangkan di kelas PMRI telah dikuasai lebih dari $75 \%$.

Hasil penelitian menunjukkan saintifik lebih efektif dibandingkan PMRI ditinjau dari minat, terlebih PMRI tidak efektif pada taraf signifikansi 5\%. Hasil penelitian ini sesuai dengan hipotesis penelitian. Meski demikian, sebenarnya peningkatan skor rata-rata pada kedua kelas setelah perlakuan hampir sama. Persentase minat siswa pada kategori sedang dan tinggi dari kedua kelas juga hampir sama. Bahkan rata-rata ditinjau dari tiap indikator pada indikator Ketertarikan, rata-rata kelas PMRI meningkat lebih besar dibanding kelas saintifik.

Berdasarkan hasil pengujian hipotesis diketahui bahwa pendekatan saintifik maupun PMRI sama-sama efektif apabila ditinjau dari percaya diri. Hal ini menolak hipotesis peneliti yang mengunggulkan PMRI dibanding saintifik.
Salah satu penyebabnya menurut peneliti adalah kedua pendekatan sama-sama berbasis konstruktivis, dimana sebelumnya telah peneliti uraikan bahwa keduanya sama-sama menekankan keaktifan siswa.

Selain itu, hipotesis penelitian ini sebelumnya disimpulkan karena tiga langkah PMRI, yakni melakukan matematisasi horisontal, mengomunikasikan secara interaktif, dan melakukan refleksi, diyakini meningkatkan percaya diri. Saintifik hanya dua langkah, yakni menanya dan mengomunikasikan. Akan tetapi, akhirnya peneliti yakin bahwa langkah menalar dalam saintifik juga mampu meningkatkan percaya diri siswa, karena dalam langkah ini siswa menemukan konsep sendiri lalu berkelompok untuk mendiskusikan hasil penalarannya. Oleh karena tiga langkah dari masing-masing pendekatan ternyata mampu meningkatkan percaya diri, maka keduanya sama-sama efektif ditinjau dari percaya diri.

Rata-rata percaya diri yang diperoleh kelas saintifik dan PMRI hampir sama. Setelah perlakuan, jumlah siswa pada kategori sedang di kelas saintifik adalah 1, dan tidak ada lagi di kelas PMRI. Peningkatan rata-rata pada kelas saintifik hampir sama dibandingkan kelas PMRI ditinjau dari tiap indikator.

\section{SIMPULAN DAN SARAN}

\section{Simpulan}

Simpulan hasil penelitian ini pada siswa Kelas VII SMP N 2 Babadan Ponorogo Jawa Timur Indonesia Tahun Ajaran 2014/2015 adalah pendekatan saintifik efektif ditinjau prestasi, minat, dan percaya diri. Pendekatan PMRI juga efektif ditinjau prestasi dan percaya diri. Pendekatan saintifik dan PMRI sama-sama efektif ditinjau dari prestasi dan percaya diri. Selain itu, pendekatan saintifik lebih efektif dibanding pendekatan PMRI ditinjau dari minat.

\section{Saran}

Saran yang dapat disampaikan menurut hasil penelitian adalah pendekatan saintifik dapat dipilih sebagai salah satu alternatif pendekatan pembelajaran yang mendukung peningkatan prestasi, minat, dan percaya diri siswa SMP. Demikian pula halnya pendekatan PMRI juga dapat menjadi pilihan bagi guru untuk meningkatkan prestasi dan khususnya percaya diri siswanya dalam belajar matematika. Saintifik dan PMRI sama-sama efektif ditinjau dari prestasi dan percaya diri, oleh karena itu bagi guru- 
guru yang terbiasa menggunakan PMRI dapat juga mencoba saintifik sebagai variasi dalam pembelajaran. Bila ingin meningkatkan prestasi, minat, dan percaya diri maka dapat digunakan perangkat pembelajaran dengan pendekatan saintifik dalam penelitian ini. Namun bila ingin meningkatkan prestasi dan percaya diri maka dapat digunakan perangkat pembelajaran dengan pendekatan PMRI dalam penelitian ini.

\section{DAFTAR PUSTAKA}

Adams, D.M., \& Hamm, M. (2010). Demystify math, science, and technology: creativity, innovation, and problem solving. Lanham: Rowman \& Littlefield Publishers, Inc.

Arthur, J., \& Cremin, T. (2010). Learning to teach in the primary school $2^{\text {nd }} e d$. London: Routledge.

Bloom, B.S. (Ed.). (1956). Taxonomy of educational objectives. Michigan: David McKay Company, Inc.

Cobern, W. W. (1993). Contextual constructivism: The impact of culture on the learning and teaching of science. Dalam K. G. Tobin (Ed). The practice of constructivism in science education (pp. 51-69). Hillsdale: Lawrence Erlbaum Associates, Inc.

De Lange, J. (1996). Using and applying mathematics in education. Dordrecht: Kluwer Academic.

Elder, G.H., Jr. (1995). Life trajectories in changing secieties. Dalam A. Bandura (Ed.). Self efficacy in changing societies (pp 46-68). Cambridge: Cambridge University Press.

Elliot, S.N., et al. (2000). Educational psychology: effective teaching, effective learning. $\left(3^{\text {rd }} e d\right)$. Boston: McGraw Hill.

Fauzan, A. (2002). Applying realistic mathematics education in teaching geometry in Indonesian primary schools. Doctoral Dissertation. Enschende: University of Twente.

Gable, R.K. (1986). Instrument development in the affective domain. Boston, MA: Kluwer Nijhoff Publishing.

Gravemeijer, K.P.E. (1994). Developing realistic mathematics education. Utrecht: $\mathrm{CD} \beta$ Press.
Hannula, M. S., Maijala, M. \& Pehkonen, E. (2004). Development of understanding self-confidence in mathematics; grades 58. Group for the psychology of mathematics education, 3, 17-24.

Hapsari, M. J. (2012). Keefektifan model inkuiri terbimbing dan direct instruction pada pembelajaran matematika ditinjau dari prestasi belajar dan kepercayaan diri siswa kelas XI IPA SMA Negeri 1 Depok Sleman. Tesis, tidak dipublikasikan. Universitas Negeri Yogyakarta.

Hosnan, M. (2014). Pendekatan saintifik dan kontekstual dalam pembelajaran abad 21: kunci sukses implementasi Kurikulum 2013. Bogor: Ghalia Indonesia.

Jurdak, M. (2009). Toward equity in quality in mathematics education. New York: Springer Science Business Media, LI.C.

Kemdikbud. (2013). Materi pelatihan guru implementasi kurikulum 2013 SMP/MTs Matematika. Jakarta: Badan Pengembangan Sumber Daya Manusia Pendidikan dan Kebudayaan dan Penjaminan Mutu Pendidikan.

Kurnik, Z. (2008). The scientific approach to teaching math. Teaching Methodology of Mathematics (Metodika), 17, 421-432.

Lefrancois, G.R. (1985). Psychology for teaching. Belmont, CA: Wadsworth, Inc.

Mendikbud. (2013). Salinan Peraturan Menteri Pendidikan dan Kebudayaan RI Nomor 65, Tahun 2013, tentang Standar Proses.

Molloy, A. (2010). Coach your self to success mimpi tercapai, target terpenuhi. (terjemahan Retnadi Nur'aini dari ASPIRATIONS: 8 easy steps to coach yourself to succes). Glenfield: Random House New Zealand.

Mulyasa, E. (2013). Pengembangan dan implementasi kurikulum 2013. Bandung: PT Remaja Rosdakarya.

O'Connor, K. (2009). How to grade for learning $K-12$. Thousand Oaks, CA: Corwin.

Oktorizal, Elniati, S., \& Suherman. (2012). Peningkatan level berpikir siswa pada pembelajaran geometri dengan pendekatan pendidikan matematika realistik. Jurnal Pendidikan Matematika, 1, 60-67. 
Ormrod, J.E. (2003). Educational psychology developing learners $\left(4^{\text {th }} e d\right)$. Upper Saddle River, NJ: Pearson Education.

Ozdemir, E., \& Uzel, D. (2011). The effect of realistic mathematics education on student achievementand student opinions towards instruction. H.U. Journal of Education, 40, 332-343.

Parson, S., Croft, T., \& Harrison, M. (2011). Engineering students self-confidence in mathematics mapped. Diakses pada tanggal 29 Maret 2015, dari https://www.google.com/search?q=Parson $\% 2 \mathrm{C}+\mathrm{S} . \% 2 \mathrm{C}+\mathrm{Croft} \% 2 \mathrm{C}+\mathrm{T} . \% 2 \mathrm{C}+\% 26+$ Harrison\%2C+M.+\%282011\%29.+Engin eering+students+selfconfidence+in+mathematics+mapped\&ie $=$ utf $-8 \&$ oe $=$ utf -8 .

Rakhmawati. (2012). Keefektifan pembelajaran kooperatif tipe STAD dan STAD plus pada materi trigonometri ditinjau dari prestasi, minat, dan motivasi belajar siswa SMA. Tesis, tidak dipublikasikan. Universitas Negeri Yogyakarta.

Sax, G. (1980). Principles of educational and psychological measurement and evaluation $\left(2^{\text {nd }} \quad e d\right)$. California: Wadsworth Publishing Company.

Schiro, M.S. (2009). Mega-fun math games and puzzles for the elementary grades. New York: John Wiley \& Sons, Inc.

Sembiring, R.K. (2010). Pendidikan Matematika Realistik Indonesia (PMRI): Perkembangan dan tantangannya. IndoMS J.M.E., 1, 11-16.

Sugiman. (2011). Peningkatan pembelajaran matematika dengan menggunakan pendekatan matematika realistik. Diambil pada tanggal 29 Maret 2015, dari http://staff.uny.ac.id/sites/default/files/tmp/2011_PPM_Iceberg_0.pdf.
Hadi, S. (2005). Pendidikan matematika realistik dan implementasinya. Banjarmasin: Tulip.

Syah, M. (2010). Psikologi pendidikan: dengan pendekatan baru. Bandung: PT Remaja Rosdakarya.

Uzel, D., \& Uyangor. (2006). Attitudes of $7^{\text {th }}$ class students toward mathematics in realistic mathematics education. International Mathematical Forum 1, 39, 1951-1959.

Van den Heuvel-Panhuizen, M. (2000). Mathematics education in the Netherlands: a guided tour Freudenthal Institute CD-rom for ICME9. Utrecht: Utrecht University.

Widiyanti, R.A. (2012). Keefektifan pendekatan PMRI dan pendekatan konvensional ditinjau dari kemampuan kognitif siswa kelas VII SMP di Kota Yogyakarta dan Bantul. Tesis, tidak dipublikasikan. Universitas Negeri Yogyakarta.

Wolf, A. (1925). Essentials of Scientific Method. London: George Allen \& Unwin LTD.

Woolfolk, A. (2007). Educational Psychology $\left(\begin{array}{ll}10^{\text {th }} & e d\end{array}\right)$. Boston, MA: Pearson Education.

Zaini, A., \& Marsigit, M. (2014). Perbandingan keefektifan pembelajaran matematika dengan pendekatan matematika realistik dan konvensional ditinjau dari kemampuan penalaran dan komunikasi matematik siswa. Jurnal Riset Pendidikan Matematika, $\quad 1(2), \quad$ 152-163. doi:http://dx.doi.org/10.21831/jrpm.v1i2. 2672

Zimmerman, B.J., Bonner, S., \& Kovach, R. (1996). Developing self-regulated learners beyond achievement to selfefficacy (psychology in the classroom). New York: American Psychological Association. 